
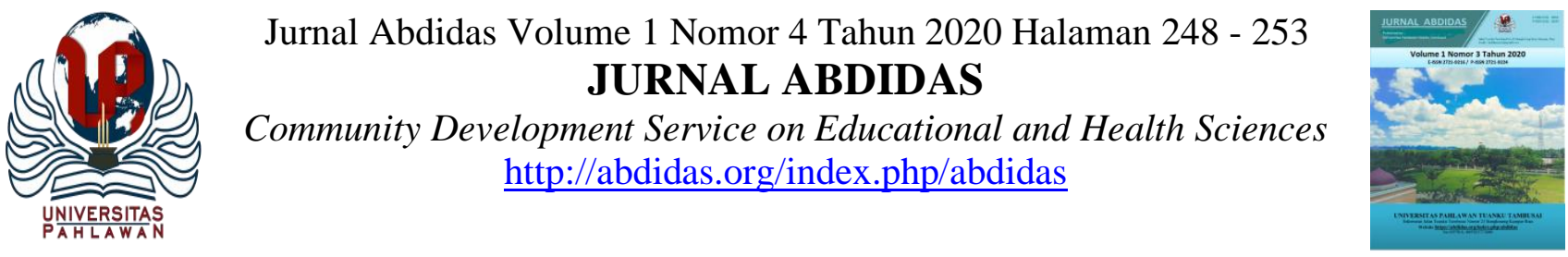

\title{
Penyuluhan Kesehatan Dan Pelaksanaan Sikat Gigi Bersama Anak SD Di Dusun Ruva Bakubakulu, Kecamatan Palolo
}

\author{
Noviany Banne Rasiman \\ Program Studi Ilmu Keperawatan, STIK Indonesia Jaya , Indonesia \\ E-mail: ophynkrasiman@yahoo.com
}

\begin{abstract}
Abstrak
Dusun Ruva adalah salah satu Dusun terpencil, di Kecamatan Palolo, Provinsi Sulawesi Tengah. Anak-anak SD di Dusun Ruva mendapatkan pendidikan dengan program kelas jauh yang hanya memiliki pengajar satu orang guru. Anak-anak SD banyak yang belum memahami cara perawatan dan menyikat gigi yang benar dikarenakan oleh kurang pengetahuan. Keadaan geografis dan ekonomi penduduknya yang kurang terpapar dengan informasi dan tidak adanya fasilitas untuk menyikat gigi. Penyuluhan kesehatan adalah kegiatan pendidikan yang dilakukan dengan cara menyebarkan pesan, menanamkan keyakinan, sehingga masyarakat tidak saja sadar, tahu dan mengerti, tetapi juga mau dan bisa melakukan suatu anjuran yang ada hubungannya dengan kesehatan. Menurut para dokter gigi, menyikat gigi dilakukan minimal dua kali sehari yaitu sehabis sarapan pagi dan sebelum tidur malam. Menyikat gigi juga dianjurkan menggunakan pasta gigi yang membantu membersihkan gigi lebih bersih dan wangi. Akibat dari jarangnya menyikat gigi adalah timbulnya plak di gigi yang diakibatkan dari penumpukan kotoran digigi. Plak gigi juga dapat menyebabkan gigi berlubang yang jika dibiarkan bisa membuat gigi ngilu. Penyuluhan dan pelaksanaan sikat gigi bersama diperlukan karena menyikat gigi memanglah kegiatan harian yang wajib dilakukan guna menjaga gigi tetap sehat dan bersih.
\end{abstract}

Kata kunci: anak SD, perawatan, menyikat, gigi, Dusun Ruva

\section{Abstract}

Ruva Village is one of the remote area, in Palolo District, Central Sulawesi Province. The Children in Elementary school at Ruva Village get education with a remote class program which only teaches by one teacher. Many elementary school children do not understand how to care and brush their teeth properly due to lack of knowledge, geographical and economic conditions of the population who are not exposed to information and the absence of facilities for brushing their teeth. Health counseling is an educational activity carried out by spreading messages, instilling confidence, so that people are not only aware, know and understand, but also want and can carry out a recommendation that is related to health. According to dentists, brushing your teeth is done at least twice a day, namely after breakfast and before going to bed at night. Brushing your teeth is also recommended to use toothpaste that helps clean teeth more clean and fragrant. The result of rarely brushing teeth is the appearance of plaque on the teeth as a result of the accumulation of dirt on the teeth. Dental plaque can also cause cavities which, if left untreated, can make teeth ache. Counseling and implementation of joint toothbrushes are needed because brushing teeth is indeed a daily activity that must be done to keep teeth healthy and clean.

Keywords: elementary school children, care, brushing, teeth, Ruva Village

Copyright (c) 2020 Noviany Banne Rasiman

$\triangle$ Corresponding author

Address : JL. Towua, No.114, Palu-Sulteng

Email :ophynkrasiman@yahoo.com

ISSN 2721- 9224 (Media Cetak)

Phone :08134115300

ISSN 2721- 9216 (Media Online)

DOI: https://doi.org/10.31004/abdidas.v1i4.54 


\section{PENDAHULUAN}

Pada bidang kesehatan gigi dan mulut pemberdayaan masyarakat merupakan salah satu cara untuk mendukung pelaksanaan pembangunan kesehatan, salah satu diantaranya dengan pemberdayaan kader kesehatan. Kegiatan yang dilakukan lebih diarahkan pada pelayanan promotif, preventif dan rujukan kesehatan gigi dan mulut yang dilakukan pada upaya kesehatan berbasis masyarakat diantaranya posyandu dengan sasaran kelompok risiko tinggi meliputi anak usia balita, anak usia pendidikan dasar, ibu hamil dan menyusui, kelompok usia lanjut (Kemenkes.RI, 2012). Kesehatan mulut penting untuk kesehatan umum dan kualitas hidup. Kesehatan mulut merupakan keadaan yang terbebas dari nyeri di mulut dan wajah, kanker mulut dan tenggorokan, infeksi dan luka pada mulut, penyakit periodontal (gusi), kerusakan gigi, kehilangan gigi, serta penyakit lainnya serta gangguan yang membatasi kapasitas individu dalam menggigit, mengunyah, tersenyum, berbicara, dan kesejahteraan psikososial (Petersen, 2009).

(Riskesdas, 2018) membahas tentang kesehatan gigi dan mulut merupakan salah satu masalah kesehatan masyarakat yang memerlukan penanganan secara komprehensif karena dampaknya sangat luas sehingga perlu penanganan segera sebelum terlambat, kebiasaan menggosok gigi merupakan hal terpenting, berdasarkan data waktu menyikat gigi menunjukkan bahwa perilaku pelihara diri masyarakat Indonesia dalam kesehatan mulut masih sangat rendah. Hal ini ditunjukkan oleh data bahwa $91,1 \%$ penduduk Indonesia sudah menyikat gigi, namun hanya 7,3\% yang berperilaku benar dalam menyikat gigi (Sari, 2014). Kesehatan gigi dan mulut merupakan bagian dari kesehatan tubuh secara keseluruhan. Kesehatan gigi dan mulut dapat merefleksikan kesehatan tubuh secara keseluruhan termasuk jika terjadi kekurangan nutrisi dan gejala penyakit lain di tubuh. Gangguan pada kesehatan gigi dan mulut dapat berdampak negatif pada kehidupan sehari-hari di antaranya menurunnya kesehatan secara umum, menurunkan tingkat kepercayaan diri, dan mengganggu performa dan kehadiran di sekolah atau tempat kerja.(Info Datin, 2019).

Karies gigi merupakan penyakit yang paling banyak dijumpai di rongga mulut bersama-sama dengan penyakit periodontal, sehingga merupakan masalah utama kesehatan gigi dan mulut. Karies gigi atau karies Dentis adalah suatu penyakit jaringan karies gigi yang diakibatkan oleh mikroorganisme pada karbohidrat yang dapat dipermentasikan sehingga terbentuk asam dan kritis. Akibatnya terjadinya dimeneralisasi pada jaringan karies gigi. Karies gigi menjadi salah satu masalah kesehatan serius pada anak usia sekolah, anak usia sekolah adalah anak yang berusia 6 sampai 12 tahun (Potter \& Perry, 2005).

Berdasarkan The Global Burden of Disease Study 2016 masalah kesehatan gigi dan mulut khususnya karies gigi merupakan penyakit yang dialami hampir dari setengah populasi penduduk dunia (3,58 milyar jiwa). Penyakit pada gusi (periodontal) menjadi urutan ke 11 penyakit yang paling banyak terjadi di dunia. Sementara di Asia Pasifik, kanker mulut menjadi urutan ke 3 jenis kanker yang paling banyak diderita.Hasil Riset Kesehatan Dasar tahun 2018 menyatakan bahwa 
proporsi terbesar masalah gigi di Indonesia adalah gigi rusak/berlubang/sakit (45,3\%). Secara nasional, menurut data (Riskesdas, 2018) sebanyak $57,6 \%$ penduduk Indonesia bermasalah gigi dan mulut selama 12 bulan terakhir, tetapi hanya $10,2 \%$ yang mendapat perawatan oleh tenaga medis gigi. Berdasarkan kelompok umur, proporsi terbesar dengan masalah gigi dan mulut adalah kelompok umur 5-9 tahun $(67,3 \%)$ dengan $14,6 \%$ telah mendapat perawatan oleh tenaga medis gigi.

Upaya pemerintah untuk meningkatkan kesehatan gigi dan mulut khususnya pada anak usia sekolah sudah sangat tinggi dengan membuat berbagai program dan kerjasama antara tenaga medis yang ada untuk menurunkan prevalensi penyakit gigi dan mulut. Kesehatan gigi dan mulut pada masyarakat diprioritasnya pada anak-anak dimana kesadaran dalam menjaga kebersihan masih rendah. Penyakit yang berhubungan dengan gigi dan mulut pada anak-anak dapat mengganggu kemampuan belajar mereka, karena usia anak-anak adalah periode peningkatan perkembangan dan kualitas hidup. Kebiasaan anak-anak untuk makan makanan manis dan kurang perhatian dari orangtua dalam hal kebersihan gigi menyebabkan risiko penyakit pada gigi lebih tinggi dibanding pada dewasa. Oleh karena itu perawatan mulut dan gigi pada anak-anak perlu dilakukan secara kontinyu.

Dusun Ruva yang merupakan salah satu Desa terpencil di Provinsi Sulawesi Tengah adalah sangat strategis untuk pembentukan karakter yang sadar perilaku hidup bersih dan sehat karena terdapat anak-anak sebagai anggota masyarakat yang tinggal dan menetap. Melalui kebiasaan tersebut, anak-anak diharapkan dapat memberikan contoh pada lingkungan sekitarnya sehingga kesehatan masyarakat dimasa depan menjadi jauh lebih baik. Salah satu upaya perilaku hidup bersih dan sehat untuk menjaga kebersihan mulut dan gigi yaitu dengan cara rajin melakukan perawatan dan menyikat gigi dengan benar.

Dusun Ruva yang merupakan salah satu Desa terpencil di Provinsi Sulawesi Tengah merupakan tempat anak-anak usia sekolah yang masih kurang mendapatkan informasi tentang kesehatan dikarenakan keadaan geografisnya. Berdasarkan observasi yang dilakukan, anak-anak di Dusun Ruva mendapatkan pengajaran di sekolah melalui program kelas jauh, dimana pengajarnya hanya satu orang guru yang mengajar untuk semua tingkatan usia dan kelas karena lokasinya yang berada diatas pegunungan. Selain itu, mereka juga memiliki pengetahuan yang rendah tentang cara perawatan dan menyikat gigi yang benar. Hasil wawancara dengan ibu guru dan kepala desa setempat, masyarakat di Dusun Ruva khususnya anak-anak SD belum pernah mendapatkan penyuluhan kesehatan tentang perawatan dan cara menyikat gigi yang benar.

Berdasarkan latar belakang tersebut, maka dilakukan pengabdian masyarakat pada anak-anak SD yang berada di Dusun Ruva, Desa Bakubakulu, Kecamatan Palolo agar mendapat perhatian tentang perilaku hidup bersih sehat khususnya tentang perawatan dan cara menyikat gigi yang benar. Setelah mengikuti kegiatan pengabdian masyarakat ini, diharapkan anak-anak SD Dusun Ruva termotivasi untuk menyikat gigi dengan rutin dan menjaga kebersihan mulut dan gigi dengan baik. 


\section{METODE}

Kegiatan pengabdian masyarakat dilaksanakan pada hari Jum'at, tanggal 17 Agustus 2018 di Dusun Ruva Kec. Palolo, Kabupaten Sigi Biromaru, Provinsi Sulawesi Tengah. Sasaran pengabdian adalah anak-anak SD yang ada di Dusun Ruva Kecamatan Palolo, Kabupaten Sigi Biromaru, Provinsi Sulawesi Tengah. Metode kegiatan yang digunakan dalam kegiatan pengabdian masyarakat ini dilakukan dengan menggunakan beberapa tahapan, yaitu survei kelompok sasaran, identifikasi kebutuhan program, persiapan sarana dan prasarana, pelaksanaan dan evaluasi.Kegiatan dilaksanakan selama 1 hari. Sebelum kegiatan penyuluhan, anak-anak SD ditanya mengenai apa yang mereka ketahui tentang cara merawat dan menyikat gigi (pre-test) secara lisan. Kemudian dilanjutkan penyuluhan cara merawat dan menyikat gigi. Dalam kegiatan praktek, tim pengabdian masyarakat memfasilitasi sarana untuk menyikat gigi dan juga memberikan seperangkat alat sikat gigi pada anak-anak SD. Kegiatan diakhiri dengan diskusi serta tanya jawab. Selanjutnya post-test yang dilakukan secaralisan.

\section{HASIL DAN PEMBAHASAN}

Sebelum pelaksanaan kegiatan pengabdian kepada masyarakat, dilakukan beberapa persiapan. Pertama, survei kelompok sasaran dengan melakukan survei lokasi dan berkoordinasi dengan Kepala Desa dan pemerintah desa yang terkait serta meminta ijin. Kedua, identifikasi kebutuhan program terkait pelaksanaan penyuluhan perawatan dan cara menyikat gigi bersama anak SD Dusun Ruva. Ketiga, mempersiapkan bahan dan alat yang mendukung program dan materi penyuluhan yang diberikan, peralatan yang digunakan untuk kegiatan praktek cara menyikat gigi.

Pelaksanaan kegiatan pengabdian kepada masyarakat yaitu selama 1 hari pada hari Jum'at, tanggal 17 Agustus 2018 bertempat di Dusun Ruva Kecamatan Palolo. Kegiatan ini dihadiri anak-anak SD dan orang tua yang mengantar anak-anak mereka yang menetap di Dusun Ruva Kecamatan Palolo.

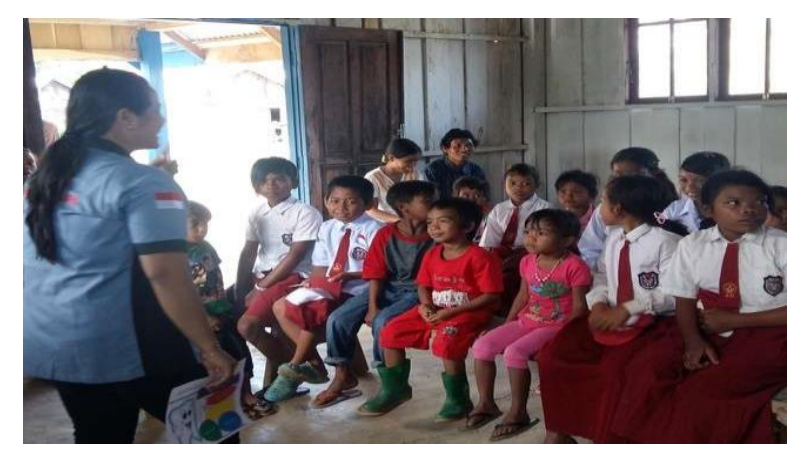

Gambar 1. Kegiatan Perkenalan Kepada Anak SD di Dusun Ruva

Sebelum dilaksanakan kegiatan penyuluhan, dilakukan pre-test kepada anak-anak SD untuk mengetahui pengetahuan dasar mereka mengenai perawatan dan cara menyikat gigi. Pre-test diberikan secara lisan dengan tanya jawab singkat.

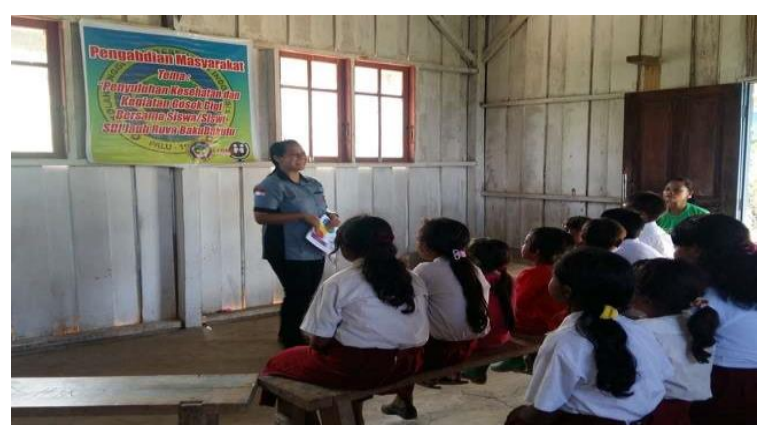

Gambar 2. Pre-Test Sebelum Penyuluhan

Setelah pre-test selesai dilakukan, kegiatan 
Penyuluhan Kesehatan Dan Pelaksanaan Sikat Gigi Bersama Anak SD Di Dusun Ruva Bakubakulu, Kecamatan Palolo - Noviany Banne Rasiman

DOI: https://doi.org/10.31004/abdidas.v1i4.54

dilanjutkan dengan penyuluhan. Penyuluhan diawali dengan pembukaan, dilanjutkan perkenalan kemudian penyampaian materi. Penyuluhan tentang perawatan dan cara menyikat gigi dilakukan dengan metode presentasi menggunkaan media leaflet bergambar. Langkah-langkah menyikat gigi: 1) menggosok gigi bagian depan dengan cara menggosok dari atas ke bawah, 2) gerakkan sikat dengan lembut dan memutar, sikat bagian luar permukaan setiap gigi, 3) gunakan gerakan yang sama untuk menyikat gigi bagian dalam, 4) gosok semua bagian gigi yang digunakan untuk mengunyah, gunakan ujung bulu, 5) sikat gigi untuk membersihkan gigi dengan tekanan ringan sehingga bulu sikat tidak membengkok, 6) untuk membersihkan gigi bagian dalam gogok gigi dengan posisi tegak dan gerakan kearah atas dan bawah melewati garis gigi. Setelah materi selesai disampaikan, dilanjutkan dengan diskusi dan tanya jawab dari peserta. Selama penyuluhan, anak-anak sangat antusias dan menyimak materi dengan seksama.

Berdasarkan pemeriksaan gigi anak-anak di Dusun Ruva, sebagian besar anak- anak memiliki gigi yang kurang bersih.

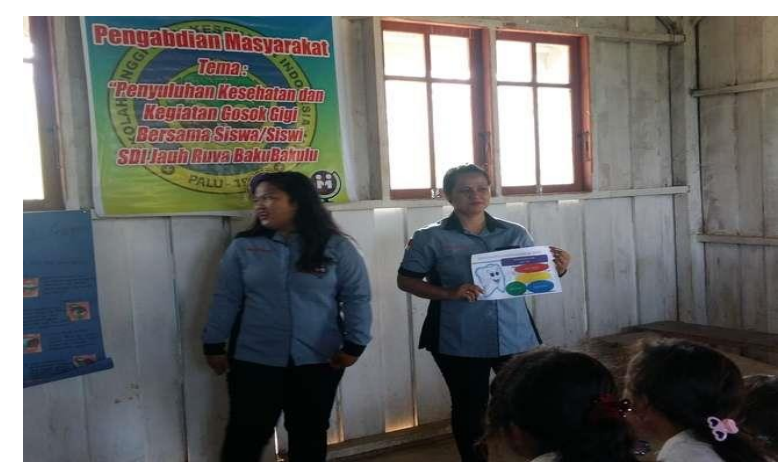

Gambar 3. Penyuluhan dengan menggunakan leaflet bergambar
Untuk mengoptimalkan output dari penyuluhan, langkah selanjutnya dengan melakukan praktek menyikat gigi oleh anak- anak SD di Dusun Ruva. Praktek menyikat gigi dilakukan dengan menggunakan alat sikat gigi yang telah dibagikan oleh panitia. Praktek ini dipandu oleh mahasiswa dan instruktur. Pertama-tama peserta diminta untuk menyiapkan air dalam gelas serta alat sikat gigi. Selanjutnya masing-masing anak mempraktekkan cara menyikat gigi dengan urutan yang telah dijelaskan dalam penyuluhan. Setelah selesai anakanak membersihkan dan menyimpan peralatan sikat gigi mereka. Setiap langkah dipraktikkan oleh masing-masing peserta hingga semua peserta bisa melakukannya. Kegiatan praktik diakhiri dengan peserta mencuci kembali tangan dengan air mengalir dan mengelap menggunakan lap yang telah disediakan sehingga tangan bersih dan melanjutkan kegiatanberikutnya.

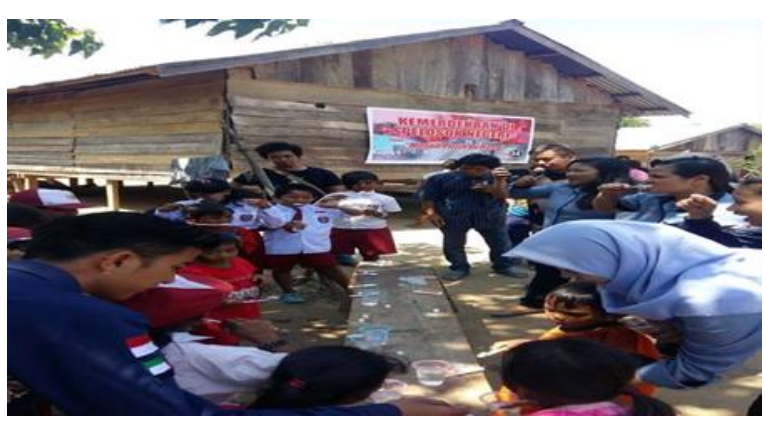

Gambar 4. Penjelasan awal Menyikat gigi

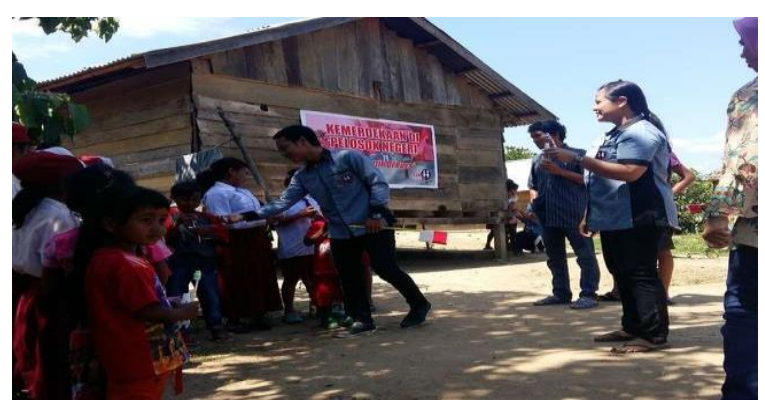

Gambar 5. Praktek Menyikat gigi 
Dengan adanya kegiatan penyuluhan perawatan dan cara menyikat gigi yang benar dapat digunakan sebagai momentum untuk memasyarakatkan perilaku hidup bersih dan sehat sehingga dapat meningkatkan kesadaran masyarakat tentang pemeliharaan dan peningkatan derajat kesehatan.

\section{SIMPULAN}

Anak-anak SD di Dusun Ruva dapat memahami cara perawatan dan menyikat gigi yang benar. Adanya kegiatan penyuluhan kesehatan tentang perawatan dan cara menyikat gigi dengan benar dapat dimanfaatkan sebagai momentum untuk memasyarakatkan perilaku hidup bersih dan sehat melalui perawatan gigi. Sehingga kerusakan gigi dapat dicegah sejak dini dan harapan meningkatkan derajat kesehatan anak-anak dapat tercapai.

Berdasarkan
pengabdian kepada
masyarakat disarankan,
mengenai perawatan dan kebiasaan menyikat gigi dengan benar harus diajarkan sejak dini, sehingga anak sudah terbiasa hidup bersih. Oleh karena itu perlu adanya dukungan dari pihak keluarga dalamhal ini orang tua dari anak-anak untuk membiasakan merawat dan menyikat gigi bagi anaknya. Kegiatan pengabdian masyarakat ini perlu adanya dukungan dari berbagai pihak baik secara moriil, ataupun materil untuk tercapainya tujuan yang diharapkan.

\section{UCAPAN TERIMA KASIH}

Ucapan terima kasih disampaikan kepada STIK Indonesia Jaya, Pendeta GPID Bukit Karmel, dan Forum Peduli Sosial yang sudah mendukung terlaksananya pengabdian kepada masyarakat, serta anak-anak SD dan masyarakat di Dusun Ruva Panti yang telah bekerjasama dalam kegiatan pengabdian kepada masyarakat sehingga kegiatan dapat berjalan dengan baik dan lancar.

\section{DAFTAR PUSTAKA}

Info Datin. (2019). Situasi Kesehatan Gigi dan Mulut.

Kemenkes.RI. (2012). Buku panduan pelatihan kader kesehatan gigi dan mulut di masyarakat.

Petersen, P. E. (2009). Global policy for improvement of oral health in the $21 \mathrm{st}$ century-implications to oral health research of World Health Assembly 2007, World Health Organization. Community Dentistry and Oral Epidemiology, 37(1), 1-8.

Potter, P. A., \& Perry, A. G. (2005). Buku ajar fundamental keperawatan: konsep, proses, dan praktik. Jakarta: EGC, 1376. https://doi.org/IOS3107-49534

Riskesdas. (2018). Laporan Hasil Riset Kesehatan Dasar (Riskesdas) Nasional 2007. Jakarta: Badan Litbangkes, Depkes RI.

Sari, S. A. (2014). Hubungan Kebiasaan Menggosok Gigi dengan Timbulnya Karies Gigi pada Anak Usia Sekolah Kelas 4-6 di SDN Ciputat 6 Tangerang Selatan Tahun 2013. 